\title{
ВІРУСНИЙ ГЕПАТИТ С ЯК ПРОФЕСІЙНА ПАТОЛОГІЯ ТА ЗАХОДИ ЩОДО ЙОГО ПРОФІЛАКТИКИ У ЛІКУВАЛЬНИХ ЗАКЛАДАХ
}

\author{
I. Г. Сковронська, Т. І. Толокова \\ ДВНЗ «Тернопільський державний медичний університет \\ імені І. Я. Горбачевського МОЗ Украӥни»
}

\begin{abstract}
У статті проаналізовано гепатит С як професійну патологію медичних працівників, його поширеність серед медичного персоналу лікувально-профілактичних закладів різних профілів, основні чинники передачі. Розглянуто найбільш важливі для практики аспекти вірусних гепатитів С: епідеміологія і профілактика. Запропоновано етапи запровадження у закладах охорони здоров'я безпечних технологій виконання інвазивних процедур, щоб запобігти випадкам уколів та порізів медичних працівників під час виконання посадових обов’язків.
\end{abstract}

\section{VIRAL HEPATITIS AS AN OCCUPATIONAL PATHOLOGY AND AS YOUR PREVENTION IN HEALTH INSTITUTIONS}

I. H. Skovronska, T. I. Tolokova

\section{Horbachevsky Ternopil State Medical University}

The article analyzes hepatitis $C$ as a professional pathology of medical workers, its prevalence among medical personnel of treatment and prevention institutions of different profiles, main factors of transmission. Considered the most important aspects of the practice of viral hepatitis C: epidemiology and prophylaxis. The stages of introduction of safe technologies for the implementation of invasive procedures in health facilities are proposed in order to prevent the occurrence of nicks and cuts of medical staff during the performance of official duties.

Вступ. Печінка являє собою центральний орган хімічного гомеостазу, який відповідає як за катаболічні, так і за анаболічні процеси організму людини, у якому створюється єдиний обмінний і енергетичний пул для метаболізму білків, жирів і вуглеводів. Актуальність проблеми здоров'я «центральної лабораторії» організму не можливо перебільшити.

Вірусний гепатит С - інфекційне захворювання печінки, збудник якого поширюється серед людей переважно шляхом абіогенної «кров'яної» трансмісії.

Biрус гепатиту C (HCV) належить до сімейства Flavivirida [2], за молекулярною структурою являє собою невелику (30-40 нм у діаметрі), вкриту оболонкою вірусну клітину [1]. Сучасна медицина виділяє 7 основних генотипів HCV (1-7) [3], які відрізняються певними особливостями епідеміології, морфології, клінічного перебігу, діагностики тощо. В Україні переважно виділяють генотипи 1 і 3.

Вірусом гепатиту С інфіковано близько 3 \% населення земної кулі. Інфікування HCV-інфекцією у 5 разів перевищує зараженість вірусом СНІДу.
Попереджаючи поширення завдяки антивірусному контролю донорської крові відбулось різке зниження гемотрансфузійного гепатиту, але інфікованість підтримується за рахунок парентеральних ін'єкційних наркотиків та інших процедур, пов'язаних із пошкодженням цілісності шкіри та слизових оболонок, що залишається ймовірним особливо щодо професійної захворюваності [1].

HCV-інфекція належить до індикаторів соціального та медичного благополуччя суспільства.

У структурі смертності від захворювань печінки гепатит С займає перше місце, у зв'язку з незвичайно високою частотою формування хронічних форм захворювання, що уражають гепатоцити та еволюціонують у цироз [4].

Статистика останніх років показала, що Україна перебуває у стані епідемії захворювання на вірусні гепатити. За ступенем негативного впливу на здоров'я населення та рівнем захворюваності вірусні гепатити в Україні займають одне з домінуючих місць в структурі інфекційної патології. 
Основна частина. Актуальність HCV-інфекції в Україні визначається швидким темпом розповсюдження і тяжкістю ранньої діагностики, що призводить до розпізнавання захворювання вже на стадіях хронізації інфекційного процесу. Парентеральний шлях передачі вірусного гепатиту С визначає зростання ризику внутрішньолікарняного інфікування здорових пацієнтів і медичних працівників при проведенні інвазивних діагностичних та лікувальних втручань [5]. Дотепер не встановлені усі чинники вірусу і хазяїна, які зумовлюють неспроможність імунної відповіді контролювати інфекцію [6].

Інтенсивне зростання числа випадків професійної патології, що реєструється в останні роки у працівників закладів охорони здоров'я, свідчить про те, що медичні працівники мають велике «парентеральне навантаження» і часто піддаються зараженню збудниками інфекційних захворювань, що передаються через кров. Вітчизняні дослідники, які вивчали гемоконтактні інфекції у працівників лікувально-профілактичних закладів, вважають, що вірусний гепатит С $\epsilon$ найчастішою інфекцією, що пов'язана з професійними обов'язками медичного персоналу, і може бути віднесена до професійних захворювань [7].

Особа, яка поранилась голкою, якою користувався інфікований на HCV, має 1,8 \% шансів заразитися цим захворюванням [8]. Ризик інфікування збільшується, якщо голка - порожниста, а рана - глибока. Попадання крові, яка містить збудник захворювання, на неушкоджену або захищену шкіру має нульовий ризик інфікування [9].
Лікарняне обладнання також $є$ чинником передачі гепатиту С у разі повторного використання голок та шприців, багаторазового використання медичного інструментарію, крапельниць чи нестерильного хірургічного обладнання [9].

Згідно з статистичними даними, найбільше випадків інфікування трапляються у палатах лікарень, процедурних та операційних відділеннях, відділеннях невідкладної допомоги. Також мають місце випадки інфікування у відділеннях інтенсивної терапії, маніпуляційних кабінетах тощо. Багато поранень відбувається під час утилізації виробів медичного призначення, забруднених біологічними рідинами [9].

Аналіз захворюваності на вірусний гепатит С за останні 5 років свідчить про те, що частота, з якою виявляють HCV-інфекцію у медичних працівників, утримується на досить високому рівні. За результатами вибіркового моніторингу показник інфікування вірусом гепатиту С серед медичних працівників, хворих на онкологічні та нефрологічні захворювання, які потребують гемодіалізу, ВІЛ-інфікованих досягає 40-60 \%, що значно перевищує середні показники у світі $[6,8]$.

Аналіз результатів захворюваності вірусним гепатитом С серед медичних працівників показує, що найчастіше інфікується медичний персонал стоматологічних закладів та поліклінік, на другому місці - працівники хірургічних стаціонарів. Найменша кількість інфікованості медичного персоналу HCV-інфекцією у пологових будинках та клініко-діагностичних лабораторіях (рис. 1).

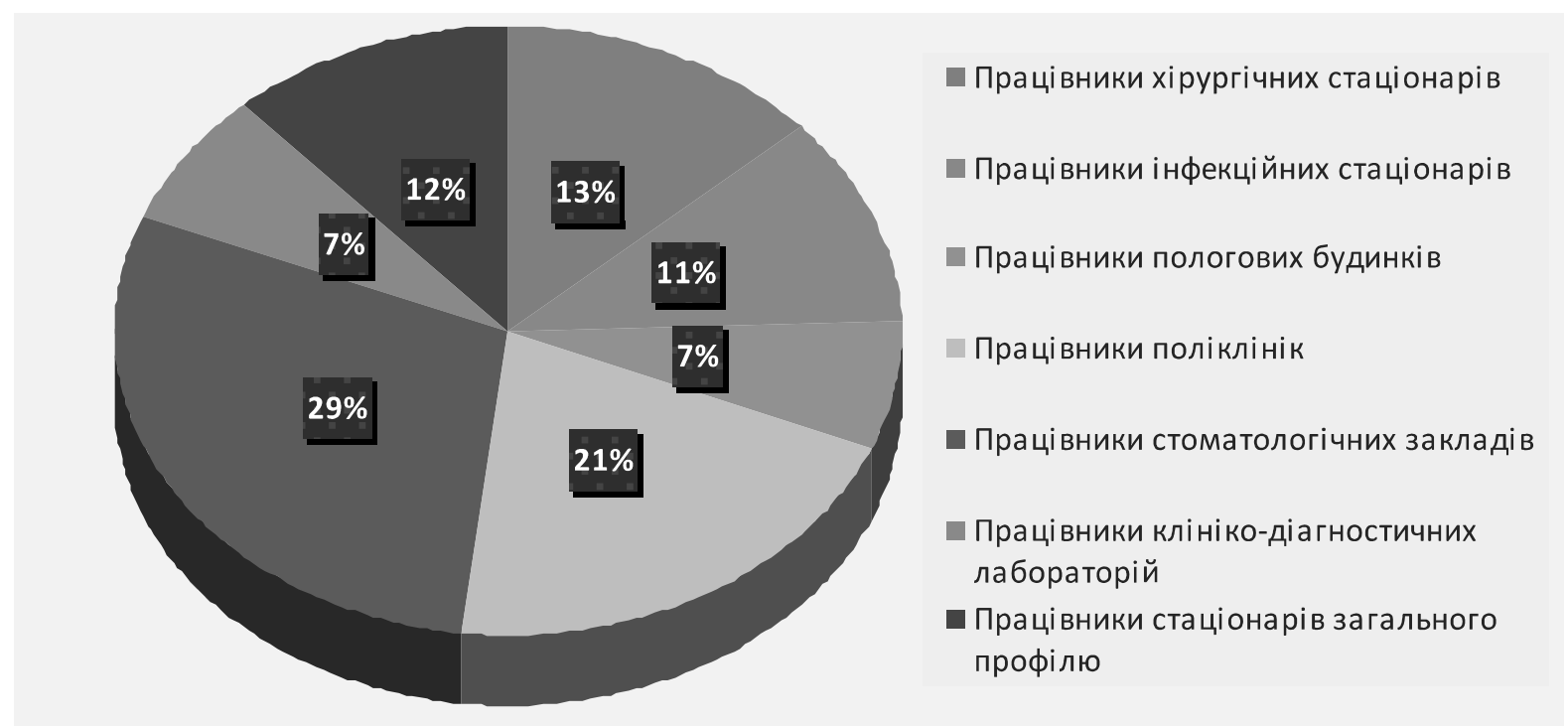

Рис. 1. Аналіз інфікованості HCV-інфекцією серед медичних працівників лікувально-профілактичних закладів України 
На нашу думку, високий рівень інфікованості HCVінфекцією серед медичних працівників стоматологічних закладів та поліклінік значною мірою зумовлений недостатнім зосередженням уваги адміністрації лікувально-профілактичних закладів до санітарнопротиепідемічного режиму та профілактики внутрішньолікарняних інфекцій.
Щоб позитивно вплинути на цю невтішну статистику, пропонуємо запровадити у закладах охорони здоров'я безпечні технології виконання інвазивних процедур та роботи з використаним інструментарієм, щоб запобігти інфікуванню медичних працівників під час виконання посадових обов'язків (табл. 1).

\section{Таблиця 1. Етапи впровадження безпечних технологій виконання інвазивних процедур}

\begin{tabular}{|c|c|}
\hline $\begin{array}{l}\text { ЕТАП 1. Оці } \\
\text { зики }\end{array}$ & $\begin{array}{l}\text { • регулярно оцінювати ризики інфікування при використанні колючого та ріжучого } \\
\text { інструментарію, голок; } \\
\text { • оцінювати ризики інфікування при контакті з біологічними матеріалами }\end{array}$ \\
\hline $\begin{array}{l}\text { ЕТАП 2. Запобігати трав- } \\
\text { муванню }\end{array}$ & $\begin{array}{l}\text { • обирати сучасне та безпечне медичне оснащення; } \\
\text { • за можливості уникати використання гострих предметів; } \\
\text { • дотримуватись стандартів поводження з гострим інструментарієм та іншими вироба- } \\
\text { ми медичного призначення }\end{array}$ \\
\hline $\begin{array}{l}\text { ЕТАП 3. Захист від трав- } \\
\text { мування }\end{array}$ & $\begin{array}{l}\text { • не варто нехтувати засобами індивідуального захисту та суворо дотримуватись пра- } \\
\text { вил їх використання; } \\
\text { • використовувати зрозуміле маркування медичних відходів та технічно безпечні кон- } \\
\text { тейнери для утилізації використаного колючого та ріжучого інструментарію }\end{array}$ \\
\hline $\begin{array}{l}\text { ЕТАП 4. Навчити персо- } \\
\text { нал правильним діям } \\
\text { при контакті з інфікова- } \\
\text { ним матеріалом }\end{array}$ & $\begin{array}{l}\text { джену шкіру чи слизові оболонки, порізі чи уколі інфікованим інструментом та ін.; } \\
\text { • пояснити необхідність інформування керівництва про випадки порізів та уколів; }\end{array}$ \\
\hline $\begin{array}{l}\text { ЕТАП 5. Відповідальність } \\
\text { керівників }\end{array}$ & $\begin{array}{l}\text { • керівники мають забезпечити страхування працівників, які працюють з біологічни- } \\
\text { ми рідинами пацієнтів та забрудненим ними інструментарієм; } \\
\text { • забезпечити своєчасне проведення постконтактної профілактики; } \\
\text { • забезпечити необхідне медичне обстеження та соціальну підтримку }\end{array}$ \\
\hline
\end{tabular}

Інформованість медичних працівників щодо вірусного гепатиту С має вирішальне значення для здійснення протиепідемічних заходів, забезпечення власної інфекційної безпеки працюючого з хворими медичного персоналу.

Висновки. Враховуючи дані моніторингу високого рівня захворюваності на вірусний гепатит С, основним завданням керівника будь-якого закладу охорони здоров'я $\epsilon$ контроль за дотриманням санітарно-протиепідеміологічного режимута профілактикою внутрішньолікарняних інфекцій. Керівник лікувально-профілактичного закладу має навчити медичних працівників правилам безпечного поводження 3 медичними виробами та біологічними матеріалами, що є потенційним джерелом інфікування. Значну увагу варто приділяти навчанню медичного персоналу шляхам запобігання інфікуванню та алгоритмам надання допомоги при виникненні травм при виконанні посадових обов'язків та своєчасному проведенню постконтактної профілактики, у разі травмування.

Інфіковані HCV медичні працівники, в епідемічному плані, можуть бути потенційним джерелом внутрішньолікарняного розповсюдження інфекції та формування сімейних вогнищ. У цій ситуації попередження професійного зараження HCV-інфекцією медичного персоналу основане на дотриманні протиепідемічних заходів у лікувальному закладі та реалізації принципів комплексного обстеження пацієнта, що включають характерну клінічну картину і дані лабораторних досліджень, які добре відомі, але залишаються необхідними для посиленого контролю за виконанням у повному обсязі. 


\section{СПИСОК ЛІТЕРАТУРИ}

1. Діагностика гепатиту C : інформаційні матеріали. Науково-виробниче об'єднання «Діагностичні системи». - C. 4.

2. Dolin, [edited by] Gerald L. Mandell, John E. Bennett, Raphael (2010). Mandell, Douglas, and Bennett's principles and practice of infectious diseases (вид. 7th ed.). Philadelphia, PA: Churchill Livingstone/Elsevier. c. 154.

3. Возианова Ж. И. Вирусные гепатиты в структуре хронической патологии печени / Ж. И. Возианова // Сучасні інфекції. - 2007. - № 4. - С. 4-9.

4. Марієвський В. Ф. Шляхи та фактори внутрішньолікарняної передачі збудників гепатитів В та С і стратегічні напрямки по зменшенню їх дії / В. Ф. Марієвський // Експериментальна і клінічна медицина. - 2005. - № 3. C. 79-83.
5. Зарицкий М. М. Берегите и защитите доктора / М. М. Зарицкий // Новости медицины и фармации. 2010. - № 8 (321). - С. 30-32.

6. Близнюк А. И. Хронические гепатиты и цирроз печени : учеб.-метод. пособие / А. И. Близнюк. - Минск : БГМУ, 2010. - 123 с.

7. Мариевский В. Ф. Риск инфицирования вирусом гепатита С пациентов и медицинских роботников в лечебных учреждениях / В. Ф. Мариевский // Врачебное дело. - 1988. - № 4. - С. 64-67.

8. WHO Hepatitis C factsheet. 2011. Процитовано 2011-07-13.

9. Довідник головної медичної сестри. - 2015. жовтень. - № 10. 